\title{
SEISMIC PERFORMANCE OF PRECAST CONCRETE BEAM-COLUMN JOINTS
}

\author{
プレキャストコンクリートの柱梁接合部の耐震性状に関する研究 \\ Juan Jose CASTRO*, Teruaki YAMAGUCHI** and Hiroshi IMAI*** \\ カストロ ホワン ホセ，山ロ輝彰, 今井 弘
}

\begin{abstract}
An experimental study on seismic behavior of precast concrete beam-column joints is presented in this paper. The objective of this study is to investigate the of seismic behavior of a newly developed precast concrete system that can make the connections more economical and easily constructed. This system is that the concrete joints are at the member ends, and the bars connections are located at the middle of precast members where the stresses are small.

Nine two thirds scale beam-column joint specimens representing a portion of a frame, including one monolithic, were tested under simulated seismic action. The behavior with respect to bending strength of beams, shear strength, bond deterioration at the beam column joint core, and energy dissipation are presented and discussed. Test results indicate that the proposed method of construction presents an adequate strength, and ductility when subjected to large inelastic deformations under cyclic loads.
\end{abstract}

Keywords : precast concrete, beam-column joint, lapping bars, bending strengh, deformation capacity, shear stress

プレキャストコンクリート, 柱梁接合部, 重水継手, 曲げ耐力, 変形能, せん断応力

\section{Introduction}

Precasting concrete for frame structures is widely known to have many attractive features. Some of which are : better quality control, savings in form works and short construction time. To find an economical and practical jointing method is one of the most important factors to take into account, in the precast concrete structures.

In a moment-resisting frame using precast concrete members, the elements must be effectively jointed to ensure that they have not only an adequate strength but also sufficient ductility to resist the seismic actions during strong earthquakes.

Numerous researches on how to connect precast concrete members have been conducted, mainly using splice sleeves, which are designed to be connected at the beam-column joints. However, there are some problems related to connection of rebars that are still left unsolved. Most of these problems are related to low energy dissipation capacity of precast members, i.e., the ability of the structure to undergo large inelastic deformations without substantial loss of strength.

Many types of moment-resisting connections have been used for joining precast concrete members. The number of possible variations is infinite, but can be roughly grouped ${ }^{11.21,3)}$ as follows:

1) In the precast concrete frame systems of the earlier days, composite units were used, as is shown in Fig. 1(a): One of the features of this rigid frame system is that connections between precast members are provided at the middle of the beams or columns, where stresses due to seismic loads are small. These connections are performed through mechanical bar joints and steel plates that provide the neccessary

* Graduate Student, Graduate School Univ. of Tsukuba, M. Eng. 筑波大学大学院 大学院生.修士 (工学)

** Chief Researcher, Technical Research Institute Kabuki Con- 株木建設·技術研究所 主任研究員 struction

*** Assoc. Prof., Institute of Engineering Mechanics, Univ. of 筑波大学構造工学系 助教授・博士 (工学) Tsukuba, Dr. Eng. 


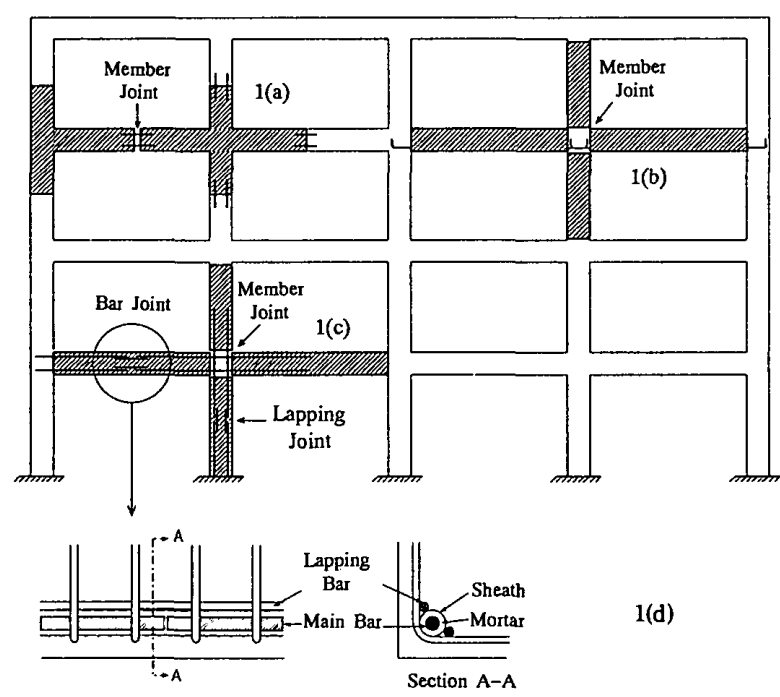

Fig. 1 Different precast concrete systems

shear transference between the precast elements. Problems such as transportation, which consequently increases the cost, and the arrangement of transverse beam, made this system disadvantageous compared with the conventional reinforced concrete system. 2) Another type developed is shown in Fig. 1(b), where the precast members are connected at the beam-column joints which are cast in-situ. In this system the lower bars and shear reinforcement of beams are embedded in the precast concrete elements. The upper bars of beams and the shear reinforcement of beam-column joint are placed at the construction site. This system has many advantages compared with the previous one. However, the connections are placed at locations where the stresses are bigger. Also the connection details are complicated, because all the lower bars of the precast beams need to be anchored in the beam-column joint. Therefore, the column dimensions need to be large enough to meet the standard minimum anchorage requirement.

In both precast concrete system shown in Fig. 1(a) and (b), the main bars are embedded in the precast concrete members so that the steel and concrete connections are to be placed in the same position.

3) Recently, a precast concrete system that has become popular is the so-called shell type system. The shell type members used in this system are left permanently in the position after casting the concrete at the site. Generally the columns are rectangular and the beams are U-shaped. The shear reinforcement and one part of the lower reinforcement of beams are embedded in the precast U-shaped beams. On the other hand the upper beam bars and shear reinforcement of beam-column joint are placed at the construction site.

4) A new concept to connect precast concrete members, for frame-type structures is proposed ${ }^{4)}$ as is shown in Fig. 1(c). In this concept, the concrete joints are at the member ends through concrete cast in-situ, and the bar connections are located at the middle of precast members where the stresses are small. Here, the columns are full precast concrete and the beams are solid half precast concrete.

When the precast members are cast, corrugated metal ducts (sheaths) are placed at the position of each main bar with two lapping bars at the sides.

At the construction site, once the precast columns and bams are positioned, the lower bars of the beams are inserted into the sheaths, so that the bars pass straightly through the beam-column joints. At this stage the shear reinforcement of beam-column joints and the upper beam bars are also placed. After inserting the column main bars from the upper side, high strength mortar is grouted inside the sheaths. To realize this, the mortar is pumped in at one inlet port (metallic tube). There is a common space that links all the sheaths at the bottom part of the column. The mortar flows up from the bottom at the same time, displacing the air progressively across the interface sheath-steel. The process is stopped when the mortar emerges from the top surface of the column. This is shown in Fig. 2. The concrete in the upper part of the beams, slabs and beam-column joint is cast next. After the upper column is set, its bottom is sealed with high strength mortar. The lower beam bars are then gouted from an inlet port located in the upper part of the beams near the beam ends. The grout cross from one sheath to the other through connectors located at the beam ends. The flow of the mortar inside the beam is also shown in Fig. 2. To ensure a good circulation of grout at the opposite side, outlet port is provided. Finally the upper column bars are grouted from an inlet port located at the bottom until the grout mortar reaches the top of the column. Once the grouting is completed the inlet ports are plugged.

Main bars are abutted at the middle of precast members, in such manner that the main bar stresses are 


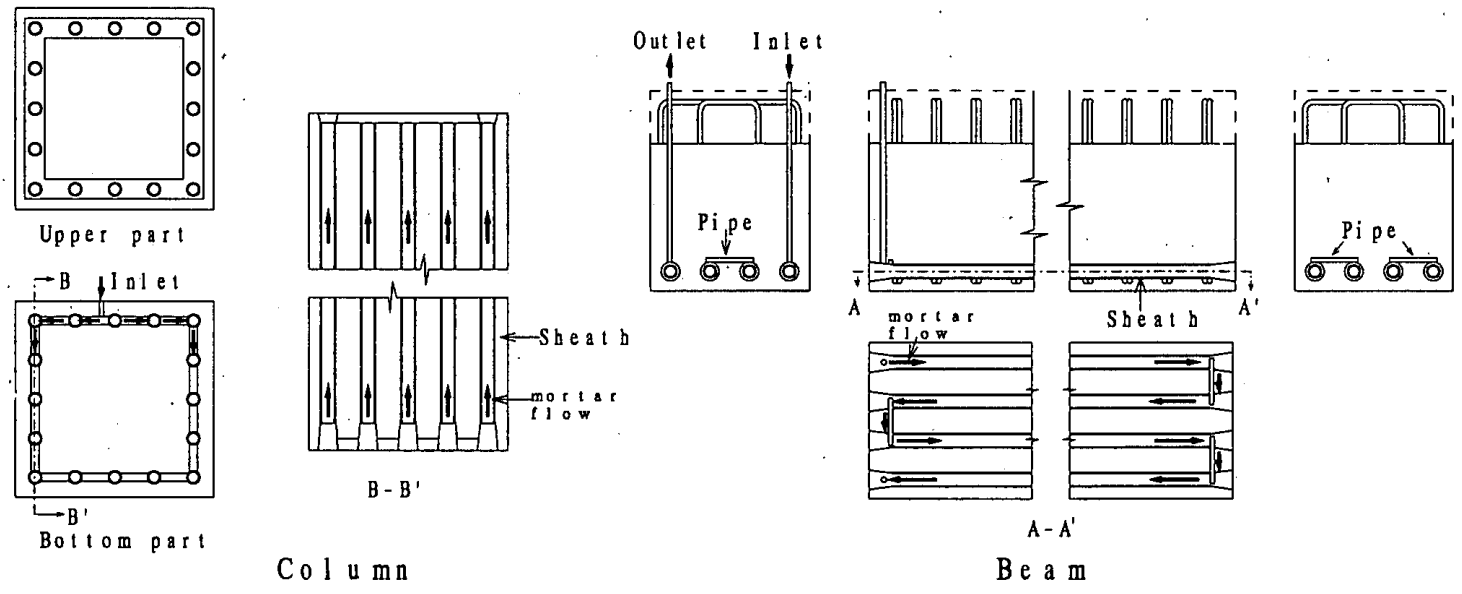

Fig. 2 Grouting methods of beams and columns

Table 1 Characteristics of precast concrete systems

\begin{tabular}{|c|c|c|}
\hline Systern & Merit & Demerit \\
\hline $\begin{array}{l}\text { 1) Column tree } \\
\text { type }\end{array}$ & $\begin{array}{l}\text { 1. Bars are jointed at small stress } \\
\text { sections. } \\
\text { 2. Bars are passing straightly } \\
\text { through the joint core. }\end{array}$ & $\begin{array}{l}\text { 1. The production of members is } \\
\text { complex } \\
\text { 2. Transportation and erection is } \\
\text { difficult. } \\
\text { 3. Workability and cost performance } \\
\text { are not good. }\end{array}$ \\
\hline $\begin{array}{l}\text { 2) Single member } \\
\text { type }\end{array}$ & $\begin{array}{l}\text { 1. Good workability. } \\
\text { 2. Easy production of members. }\end{array}$ & $\begin{array}{l}\text { 1. Bar arrangement at the joint core } \\
\text { is difficult. }\end{array}$ \\
\hline 3) Shell type & $\begin{array}{l}\text { 1. Some bars can be placed straightly } \\
\text { at the beam-column joint and } \\
\text { connected at small stress sections. } \\
\text { 2. Easy transportation. }\end{array}$ & $\begin{array}{l}\text { 1. Shell concrete with subties is } \\
\text { difficult and expensive to produce. }\end{array}$ \\
\hline 4) New system & $\begin{array}{l}\text { All the merits above mentioned are } \\
\text { valid. }\end{array}$ & $\begin{array}{l}\text { It is necessary to improve the } \\
\text { technic for grouting of mortar. }\end{array}$ \\
\hline
\end{tabular}

transferred to the mortar and then to the lapping bars through the sheaths by bond stress. Fig. 1(d) shows the outline of the connection system. Table 1 shows some of the advantages and disadvantages of the above mentioned precast systems.

This experiment was undertaken to verify the applicability of the system presented herein, with emphasis on the beam-column joints. The project includes

the experimental evaluation of its performance under seismic actions and its comparison with those of similar monolithic connections. Also, the aim of this experiment was to evaluate the influence of main bars arrangement (located in one or two layers), the ratio of main bar diameter to the column depth $(d / D)$, that is the anchorage length of main bars inside of the beam-column joints, and the beam-column joint safety factor, on the seismic performance of the specimens which were built using the present system. Furthermore, one specimen was provided with prestressing bars to study its leverage on the cracks control.

\section{Experimental Program}

\subsection{Specimen}

Nine 2/3 scale specimens were used to carry out this experiment. The dimensions of a typical test specimen are shown in Fig. 3. The specimens representing the portion of an interior beam-column subassemblage taken out from the lower story of a middle-rise frame building, were subjected to cyclic lateral loading with constant axial force to simulate the earthquake action. Only the loads acting on the plane were considered.

The characteristics of the individual specimen are summarized in Table 2. The specimens were designed so that the plastic hinges at the beam ends occur before flexural yielding in the columns and shear failure in the beams, columns and beam-column joints, except for Specimens JPC-24, JPC-25 and JPC-28. These specimens were designed to fail in shear at the beam-column joint. Table 2 shows the ratio of the ultimate moment of columns to the moment induced by the beams on the columns, usually known as moment ratio.

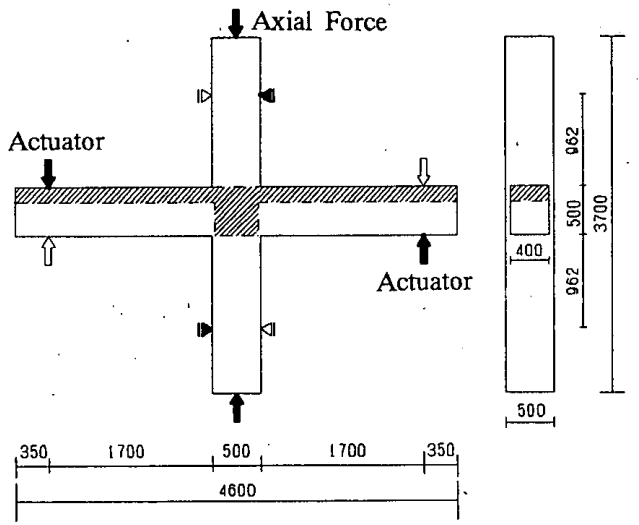

Fig. 3 Outline of the test specimen 
Table 2 Characteristics of specimens

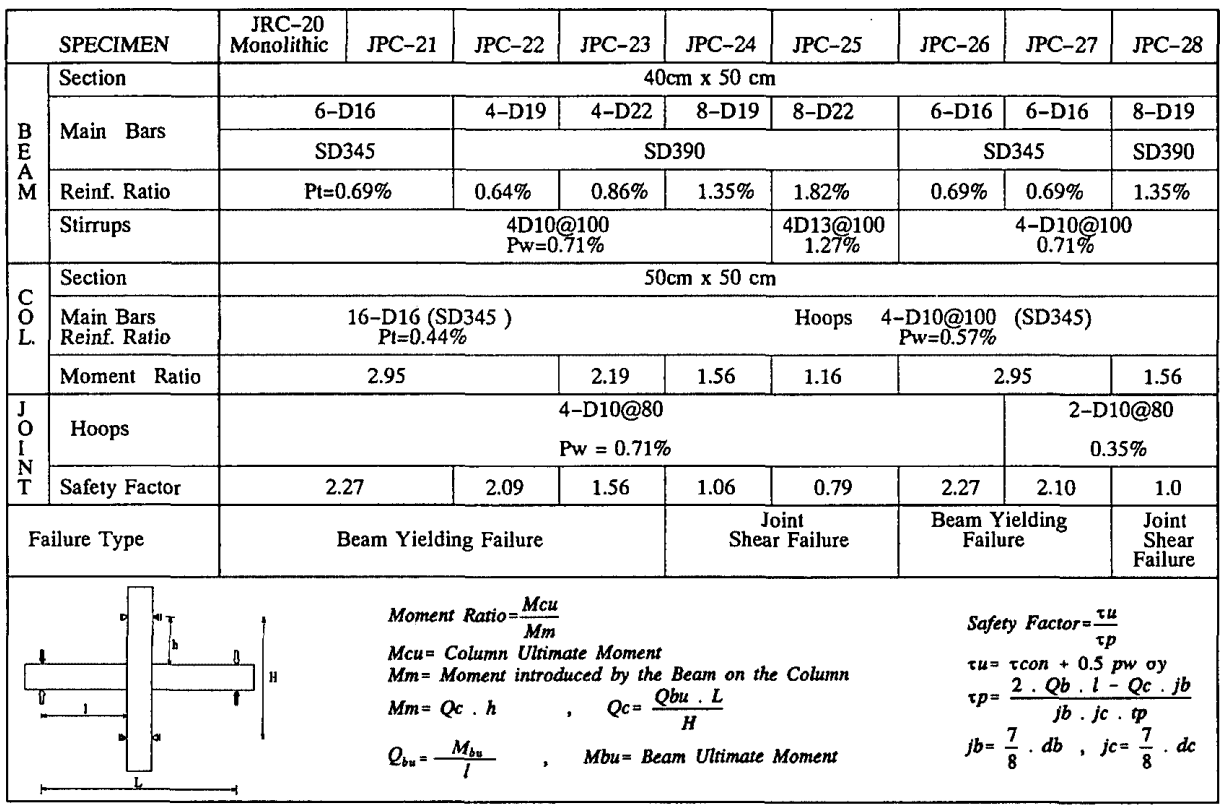
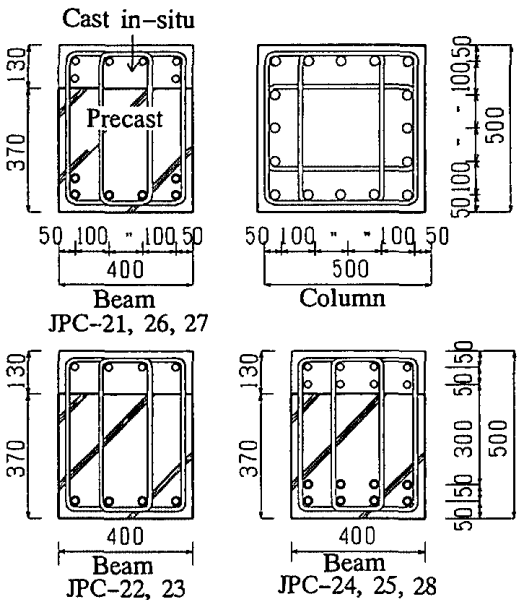

Fig. 4 Details of member sections

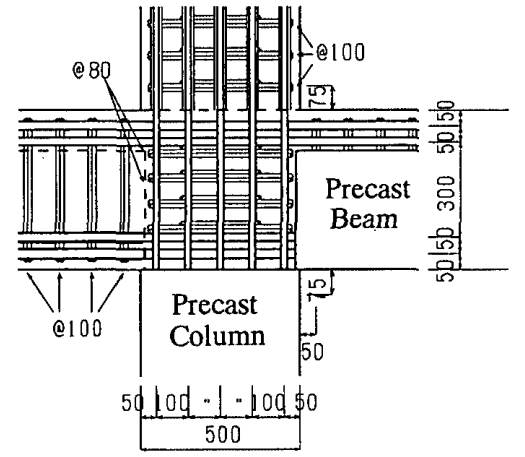

Fig. 5 Bar arrangement of specimens
Based on this ratio, it is possible to determine whether the beams will fail before the columns. This table also shows the ratio of the theoretical shear strength of beam-column joints $\tau_{u}$ (calculated by Kamimura's formula) to the shear strees of beam-column joints calculated using the ultimate moment of the beams. On the basis of this ratio, called joint safety factor, it is possible to determine

whether the joint will finally fail in shear or not.

All specimens had columns with identical cross section $(50 \mathrm{~cm} \times 50 \mathrm{~cm})$, reinforced with 16 longitudinal bars of D16 (deformed bar of $16 \mathrm{~mm}$ diameter) passing through the joint. The transverse reinforcements were 4-D10 welded closed rectangular hoops at $10 \mathrm{~cm}$ spacing.

The beams were a composite cross section of $40 \mathrm{~cm} \times 50 \mathrm{~cm}$ as is shown in Fig. 4. The beam longitudinal bars were placed in one or two layers. For beam yielding specimens, to maintain the longitudinal reinforcement ratio of beams $\left(p_{t}\right)$ reasonably close to each other different size of bars were selected.

All specimens had the beam-column joint reinforced with 4-D10 deformed bar stirrups at $8 \mathrm{~cm}$ spacing. Fig. 5 shows the bar arrangement used for a typical specimen.

To improve the shear transference all precast beams were provided with two shear cotters at the extreme surface, with $50 \mathrm{~mm}$ height, $300 \mathrm{~mm}$ length and $7 \mathrm{~mm}$ thickness. This can be seen in Fig. 6 . To facilitate the development of the interface bond between the precast beam and the cast in-situ concrete, the top surface of precast concrete was intentionally roughened by wire brushing.

Specimen JPC-26 was provided with two prestressing bars located at mid-depth of the precast beams to study its influence on the precast concrete. Since the prestressing bars terminate at the end of the precast beam they are not anchored in the beam-column joint core. The prestressing load applied was 
$40 \mathrm{kgf} / \mathrm{cm}^{2}$. Fig. 6 also shows a detail of the steel plate used to anchor the prestressing bars.

The monolithic specimen JRC-20 was cast in vertical position as is done in real structure. There were two pours for this specimen. First for the lower column, beams, and beam-column joint, and second for the upper column.

All the precast concrete members were cast in horizontal position. Beam-column joints and the upper part of the beams were cast in the same orientation as in real structure and according to site practice.

The sheath had $34 \mathrm{~mm}$ exterior diameter, $30 \mathrm{~mm}$ interior diameter, $2 \mathrm{~mm}$ lug height, and $0.25 \mathrm{~mm}$ thickness, for all precast members.

The specified compressive strength used for precast and cast in-situ concrete was $300 \mathrm{kgf} / \mathrm{cm}^{2}$, and $600 \mathrm{kgf} / \mathrm{cm}^{2}$ for the grout mortar. The compressive strength of concrete and yield stress of steel are shown in Table 3 . Table 4 shows the compressive strength of the grout mortar. The loading of

Table 3 Steel and concrete strength properties.

\begin{tabular}{|c|c|c|c|c|c|c|c|c|c|c|}
\hline \multicolumn{2}{|c|}{ Specimen } & \multicolumn{9}{|c|}{\begin{tabular}{|l|l|l|l|l|l|l|l|l|} 
JRC-20 & JPC-21 & JPC-22 & JPC-23 & JPC-24 & JPC-25 & JPC-26 & JPC-27 & JPC-28 \\
\end{tabular}} \\
\hline \multirow{4}{*}{$\sigma y$} & Column Bars & \multicolumn{9}{|c|}{$\begin{array}{l}\text { D16 } \\
3730\end{array}$} \\
\hline & COTunim Das & & & D19 & D22 & D19 & D22 & & 516 & $\begin{array}{l}\text { D19 } \\
4300\end{array}$ \\
\hline & Stimups & \multicolumn{4}{|c|}{$\begin{array}{l}\text { D10 } \\
3620\end{array}$} & & $\begin{array}{l}\text { D13 } \\
3740 \\
\end{array}$ & \multicolumn{3}{|c|}{$\begin{array}{l}\text { D10 } \\
3620\end{array}$} \\
\hline & Joint Hoops & \multicolumn{9}{|c|}{$\begin{array}{l}\text { D10 } \\
3620 \\
\end{array}$} \\
\hline \multirow{3}{*}{$\sigma \mathrm{c}$} & Beam & 348 & 347 & 347 & 347 & 347 & 347 & 342 & 347 & 347 \\
\hline & Column & 348 & 385 & 385 & 385 & 344 & 385 & 375 & 344 & 344 \\
\hline & Joint & 348 & 319 & 319 & 319 & 341 & 319 & 334 & 341 & 349 \\
\hline
\end{tabular}

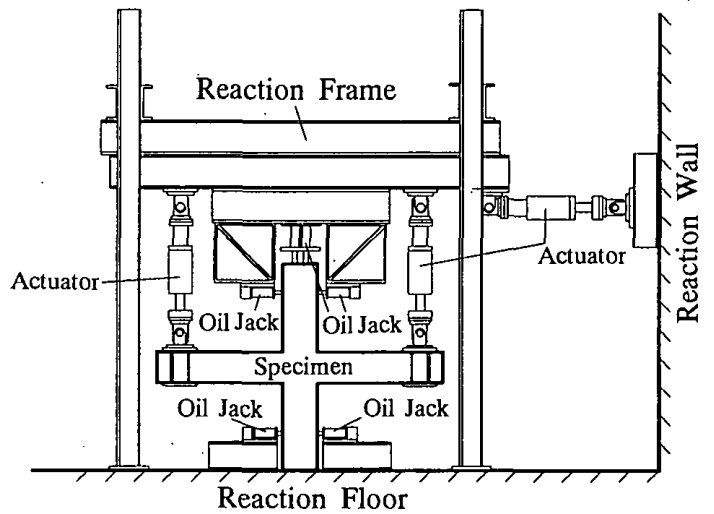

Fig. 7 Loading system

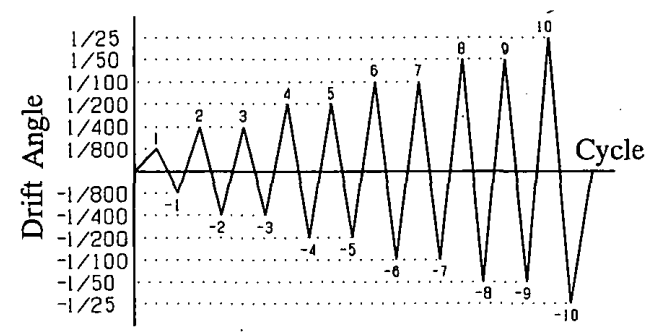

Fig. 8 Loading history
Table 4 Grout mortar strength properties

\begin{tabular}{|l|c|c|c|}
\hline \multirow{2}{*}{ Grout Mortar } & \multicolumn{3}{|c|}{ Compressive Strength } \\
\cline { 2 - 4 } & 7 days & 4 weeks & 8 weeks \\
\hline Lower Column & 598 & 689 & 772 \\
\hline Upper Col. and Beam & 562 & 632 & 710 \\
\hline
\end{tabular}

Units: $\mathrm{Kgf} / \mathrm{cm}^{2}$

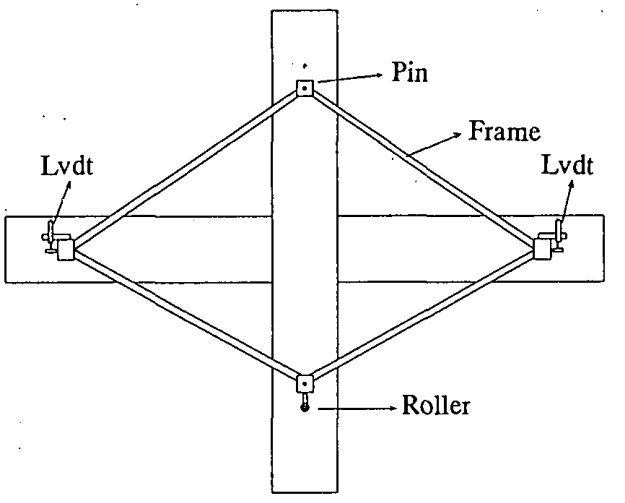

Fig. 9 Total deformation measuring devices

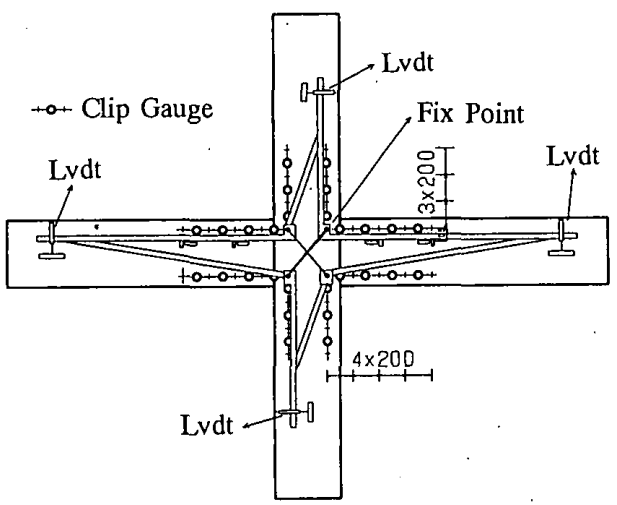

Fig. 10 Partial deformation measuring devices 
specimens started four weeks after the last grouting was carried out.

\section{2 Loading System and Instrumentation}

The specimens were subjected to cyclic loads by means of the action of vertical actuators located at both beam ends. This is to ensure that the distribution of bending moments and shear forces will be the same as those of a beam-column joint in a laterally loaded moment resisting frame. There was a horizontal actuator used to control the displacements of the loading frame. The loading system and loading history are shown in Fig. 7 and Fig. 8 respectively. To simulate gravity loads, an axial force of 150 tons $\left(\sigma_{0}=N / b D=60 \mathrm{kgf} / \mathrm{cm}^{2}\right)$ was applied on the top of the column.

To restrain the movement within the plane, both ends of the column were supported by oil jacks at both sides. To lessen the friction, teflon plates were attached at both ends of the column. There were two sets of devices to measure the deformation of specimens. The total deformation was measured with displacement transducers located at the beam ends. These transducers were fixed on a diamond-shaped frame supported by a pin at the upper column and with a roller support at the lower column, which allow the movement only in the vertical plane. This is shown in Fig. 9. The lateral drift angle $R$ in this paper is defined as the sum of the displacements of beams over the distance between the loading points.

To measure the partial deformation of members, four frames were attached to the corners of the joint. From these points two clip gauges were placed diagonally to measure the joint shear deformation. The curvature of beams and columns were also measured through clip gauges as shown in Fig. 10. Strain gauges were used to monitor the strains at the beam and column reinforcements.

\section{Test Results}

\subsection{Crack Patterns}

The crack patterns observed at $R=1 / 50 \mathrm{rad}$. of all specimens are shown in Fig. 11. For specimens designed as a beam yielding type, nearly vertical cracks due to flexure were developed only on the beams since the first cycle of loading. At $1 / 200 \mathrm{rad}$, , when the main bars started to yield, the high strength mortar used to fix the precast concrete column to the joint, also presented flexural cracks. The shear cracks in the beam-column joint were observed at $1 / 100 \mathrm{rad}$. In that sense JRC-20, JPC-21, JPC-22 and JPC-27 presented very similar crack patterns. JPC-23 showed also similar characteristics in the beams, but compared with JPC-22, at yield point it had already suffered noticeable shear cracking in the beam-column joint area. Also at the final stage JPC-23 had substantially more cracking. This was to be expected since the bond conditions in the beam column joint were better for JPC- 22 . The columns did not experience any significant cracking.

For specimens designed to fail in shear at the beam-column joint (JPC-24, JPC-25, JPC-28) joint shear cracks started at $1 / 400 \mathrm{rad}$. At the final stage, these specimens presented a typical shear failure crack pattern with the joint heavily affected by the shear stress. In spite of less beam-column joint shear

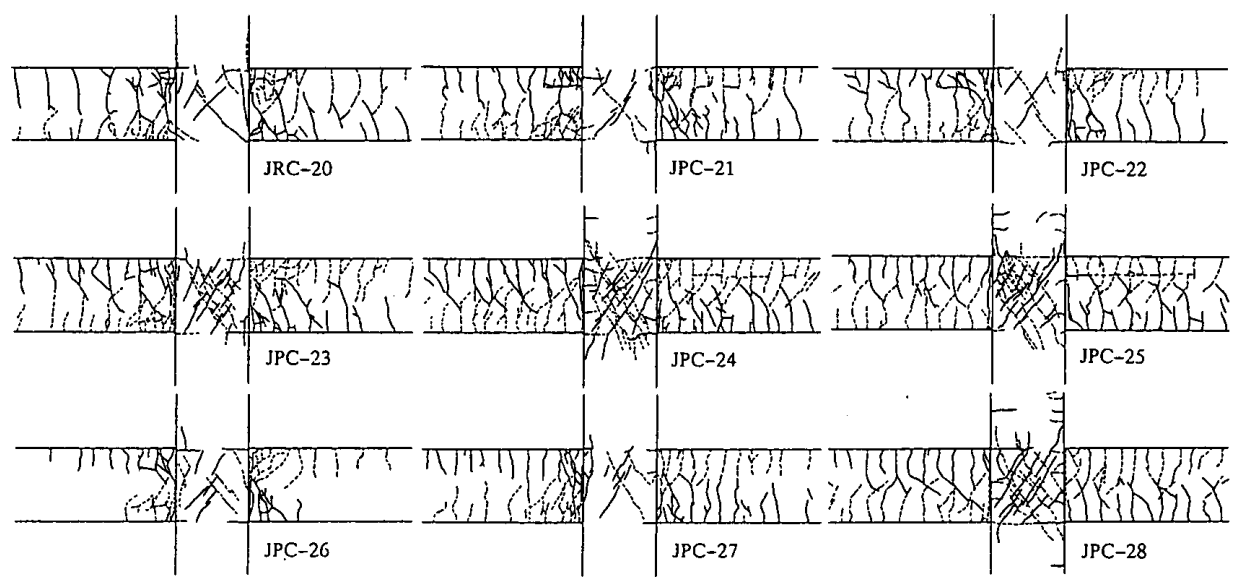

Fig. 11 Crack patterns 
reinforcement of JPC-28, no remarkable differences could be observed from the crack pattern. Compared with JPC-21, Specimen JPC-26 with 2 prestressing bars located at the mid-depth of precast portion of beams showed few cracks concentrated on the precast concrete portion near the column face. On the other hand, flexural cracks similar to JPC-21 were observed on the cast in-situ portion of the beams.

\section{2 Load-Deflection Relationship}

The beam load-beam deflection relationships are shown in Fig. 12. The summary of the test results and the comparison with the calculated values are shown in Table 5. The actual material properties were used for theoretical calculations.

Specimens JRC-20, JPC-21 and JPC-27 with same tensile reinforcement ratio $p_{t}=0.69 \% \quad(6-\mathrm{D} 16$, SD 345) and anchorage length of 31 times the bar diameter, presented very similar hysteretic shape. The outer layer of beam main bars started to yield at the column face once $R$ was $1 / 200 \mathrm{rad}$. No strength decay was observed and the maximum load was reached at the last cycle $(1 / 25 \mathrm{rad})$. The ultimate capacities reached by these specimens were $18 \%$ or higher than those obtained by analytical methods, probably because the main bars get into the strain hardening zone.

Specimen JPC-22 with $p_{t}=0.64 \%$ (4-D 19, SD 390) and anchorage length of 26 times the diameter showed similar hysteretic loops, compared to those of the above mentioned specimens. At the last cycle also a little stiffness reduction could be observed due to yield penetration in the beam-column joint.

Specimen JPC-23, with $p_{t}=0.86 \%$ (4-D 22, SD 390) and anchorage length of 23 times the diameter showed a good hysteretic shape. These specimens reached their ultimate capacity at the last cycle and exceed by $10 \%$ the analytical value. Also for these two specimens, the main bars started to yield at $R=1 / 200$, and strength reduction was not observed when the displacement amplitude reached the previous maximum value.

Specimen JPC-26 showed similar behavior compared to JPC-21, However since the beam main bars started to
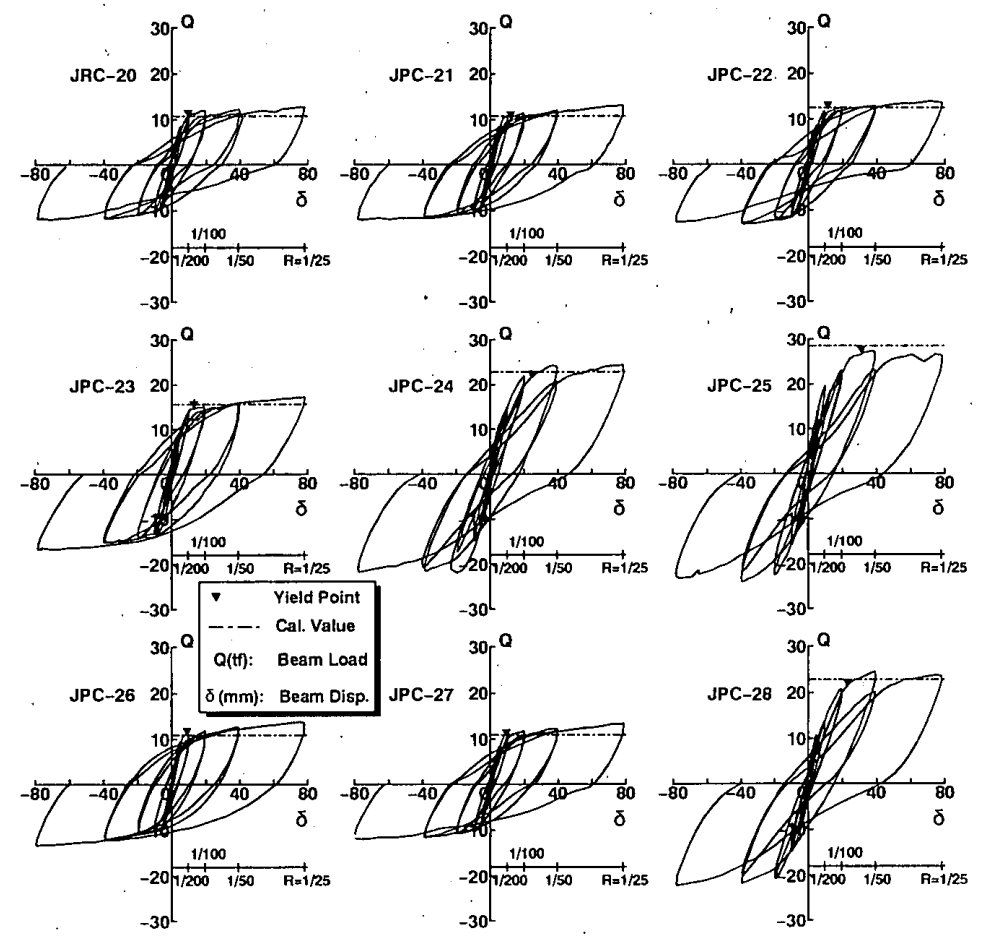

Fig. 12 Beam load-beam deflection relationship

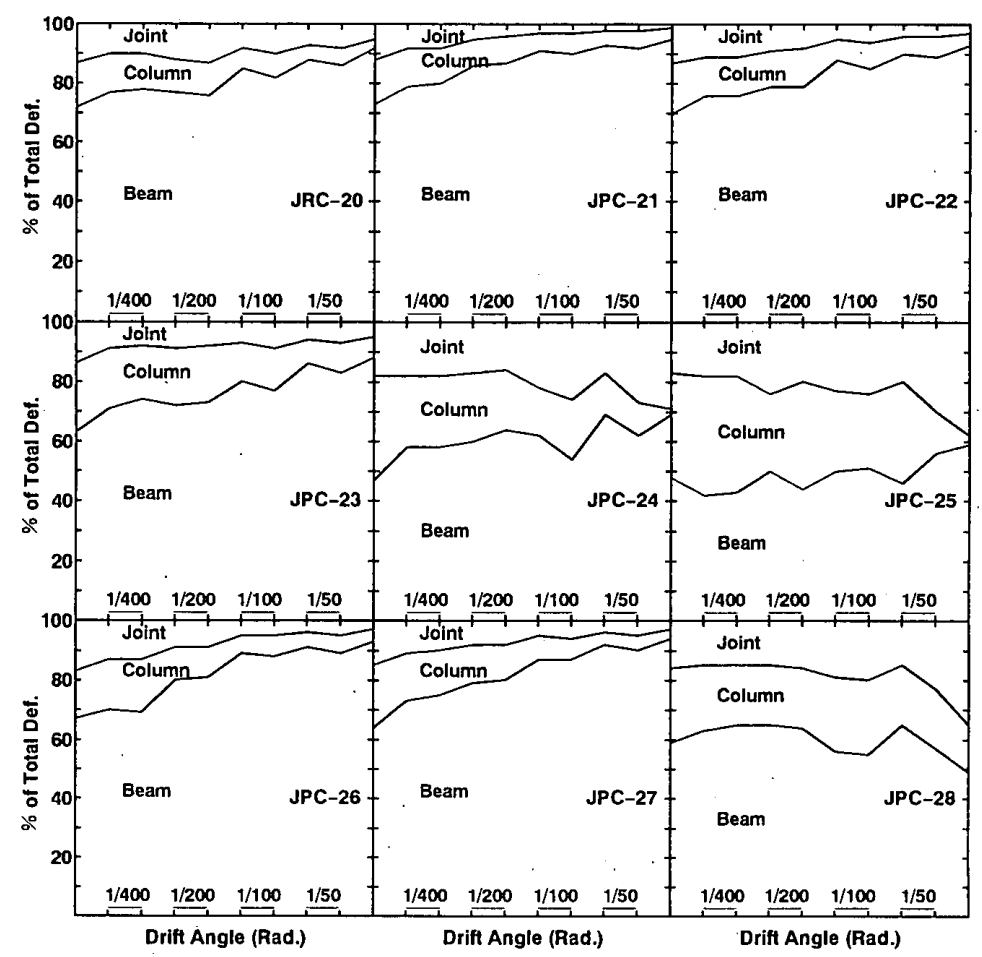

Fig. 13 Deformation components 
yield at $R=1 / 200$, the specimen showed very ductile hysteresis loops as a consequence of strain hardening provided by the prestressing bars, which let to have more energy dissipation.

For Specimens JPC-24 and JPC-28 designed as joint shear failure type, the main beam bars yielded before the drift angle reached $1 / 50 \mathrm{rad}$. A little strength decay was observed in these three specimens at the second cycle of $R=1 / 50$ because of the joint shear failure. Specimen JPC-25 showed similar pattern, however did not reach its ultimate capacity due to joint shear failure.

\section{3 Deformation Components}

The contributions of beam, colum and beam-column joint to the total deformation at positive loading cycles are shown in Fig. 13. Each contribution is expressed as percentage of the total deformation. There were no remarkable differences between JRC-20 and JPC-21. JPC-27, which had half of the beam-column joint shear reinforcement $\left(p_{w}\right)$ of JPC-21, shows also similar pattern. For these three specimens, the largest contribution ( 60 to $90 \%$ ) was by the beams, and with cyclic load, the beam contribution increases while the beam-column joint and column contributions decrease. For Specimens JPC-22 and JPC-23, almost the same patterns can be observed since the longitudinal reinforcement ratios pt were similar. JPC-23 shows the column and beam-column joint deformation is a little bigger than JPC-22. The beam-column joint contribution for JPC-23 has few variations with the cyclic load.

JPC-24 and JPC-28 present similar values for the deformation components up to $R=1 / 50$ where the joint failed in shear. After which, the joint deformation component for JPC-28 increased significantly. For JPC-25, the joint failed in shear at $R=1 / 50$. In this specimen, the beam also failed at the same loading stage.

\section{4 Horizontal Slip Deformation at the Casting Joint of Beam}

The relationship of the beam load and beam slip deformation between the precast and cast in-situ concrete for specimens JPC-21, JPC-22, JPC-24, and JPC-26 are shown in Fig. 14.

Specimen JPC-21, with almost $3 \mathrm{~mm}$ at the last stage, showed the biggest displacement at the measuring point near the column face. This is in correspondence with the observed crack pattern which present cracks along the contact surface. On the other hand, for the rest of the specimens, the displacements were limited to 0.2 up to $0.8 \mathrm{~mm}$. This was to ensure an almost monolithic behavior of the beam itself.

\section{5 Beam-Column Joint Shear Distortion}

The beam-column joint shear stress-shear distortion relationships are shown in Fig. 15. The effective beam-column joint area to resist the shear stress is defined as the column effective depth multiplied by

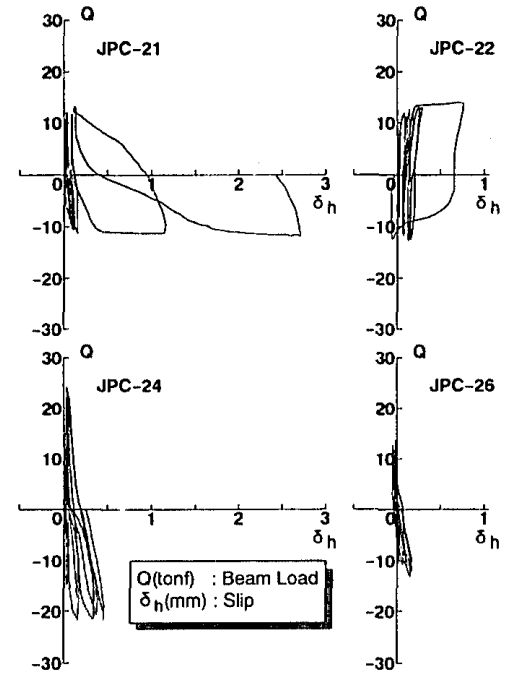

Fig. 14 Horizontal slip deformation at casting joint of beams

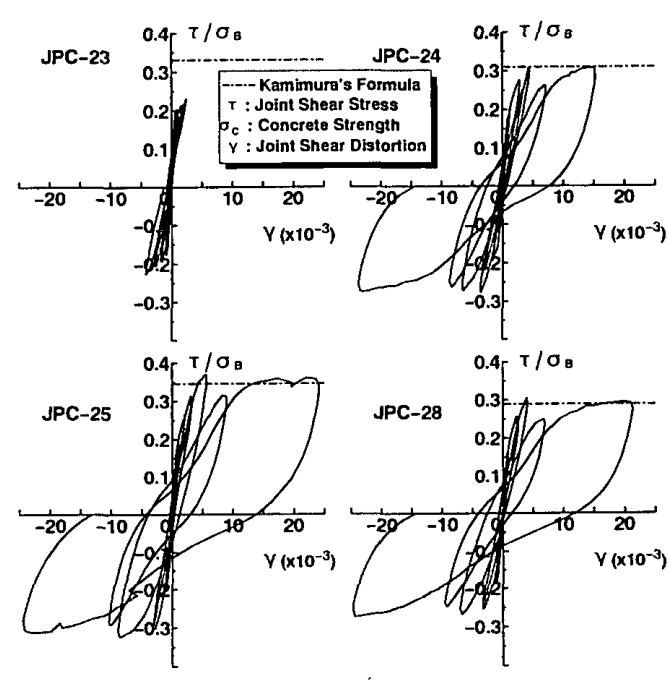

Fig. 15 Joint shear stress-joint-shear distortion the average of the beam and column widths. There was no significant difference among specimens designed as beam yielding type, where the beam-column joint shear distortion was insignificant.

Specimens JPC-24 and JPC-28 present similar hysteretic curves up to $R$ $=1 / 50 \mathrm{rad}$. where the beam-column joints failed in shear. At the last cycle the joint deformation of 
JPC-28 was $30 \%$ higher than that of JPC-24 due to the less reinforcement placed in the beam-column joint. At this stage, both specimens reached their maximum shear stress. Also JPC-25 failed in shear, but at $1 / 50 \mathrm{rad}$, the shear stress reached the maximum value. Table 5 shows the experimental and the analytical results.

For Specimen JPC-25, the ratio between the experimental and analytical data shows a good approximation with Kamimura's formula ${ }^{5 !}$.

Figure 16 shows the beam-column joint shear strength test results obtained in the past for monolithic interior beam column joints, for different precast systems and for the system proposed in this paper. The results show that the shear strength values obtained for the present system were similar to those of monolithic systems and even higher than those obtained for others precast concrete system ${ }^{71}$.

\section{6 Moment-Curvature Relationship of Beams}

Figure 17 shows the beam moment at the column face-curvature at different sections along the beams. The sections are defined by the positions of the clip gauges attached to beams. The hysteretic curves for the section adjacent to the column face showed that the beams behaved almost in elastic way up to $R=$ $1 / 200$.

For the specimens designed as a beam yielding type, the curvatures show that the deformation was concentrated not only in the section adjacent to the column, but was also spread along the beam, up to the second section defined by the clip gauges, $30 \mathrm{~cm}$ from the column face.

Figure 18 shows the variation of the average curvature (measured through the clip gauges) at the column face with the lateral drift angle. The curvature of JPC-20 is slightly smaller than JPC-21, However, at the last stage, it has a higher value owing to large deformation at the column face. Same phenomenon was observed for Specimen JPC-26 which exhibits larger curvature compared to all other specimens. This is because the prestressing bars did not allow the deformation to spread along the beam.

\subsection{Strain and Bond Stress Distribution of Beam Bars}

Measured strains along the length of the bottom longitudinal bars are shown in Fig. 19. Solid lines represent the distribution for the positive loading direction and broken lines in the negative direction.

After the main bars yielded in tension at $R=1 / 200 \mathrm{rad}$, , the compressive side of the critical sections of the beam showed no tendency to change the strains from compression to tension. However the lower bars of JPC-23 showed a tendency to change the strains from compression to tension at the compression side. This situation is likely associated with the crack pattern showed by this specimen, where many shear cracks were developed at the beam-column joint.

For other specimens, no differences were observed between the behavior of top bars embedded in the 


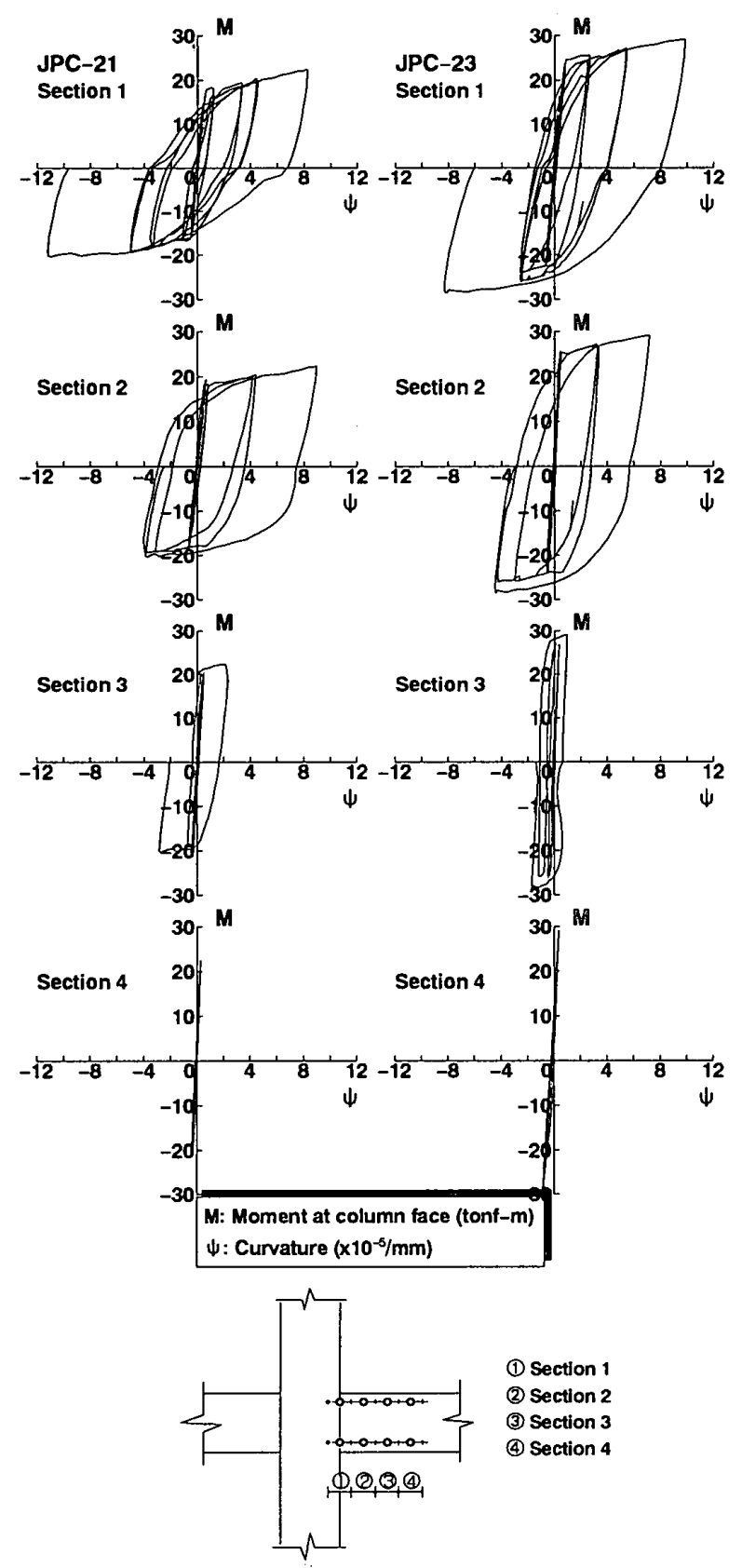

Fig. 17 Moment-curvature relationship of beams
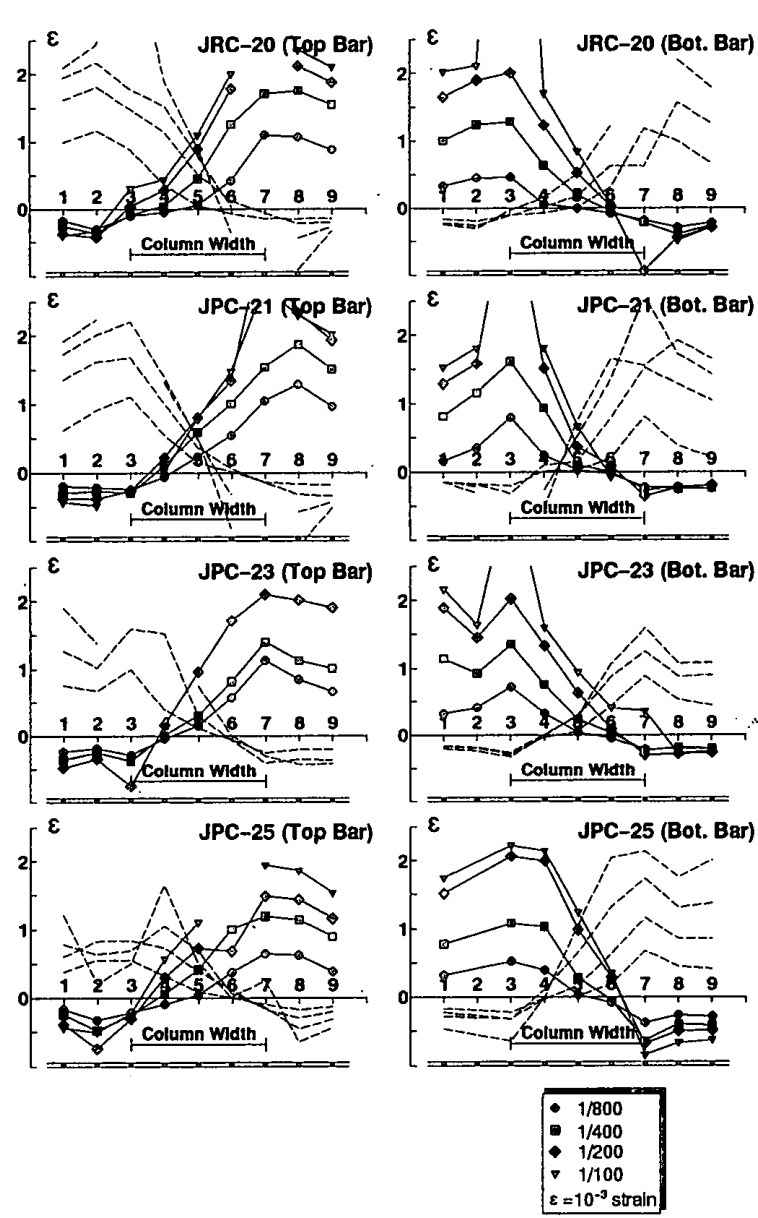

Fig. 18 Beam end curvature

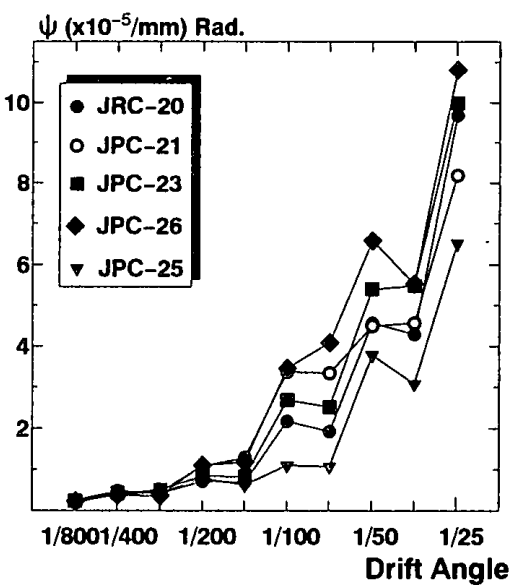

Fig. 19 Strain distribution of beam bars

cast in-situ concrete and the bars located in the precast members.

The average bond stress distributions of the lower beam main reinforcements at peaks of each loading cycle are shown in Fig. 20. The measured steel strains in inelastic range were converted to stresses using the Ramberg-Osgood model. The average bond stress was calculated from the difference of stresses between two consecutive sections multiplied by the bar section and divided by the perimeter and the longitude of interval.

The general tendency is that the average bond stress increases with the deformation. For Specimen JPC-23, bond stress $\tau$ was slightly smaller than that developed by the other specimens. 

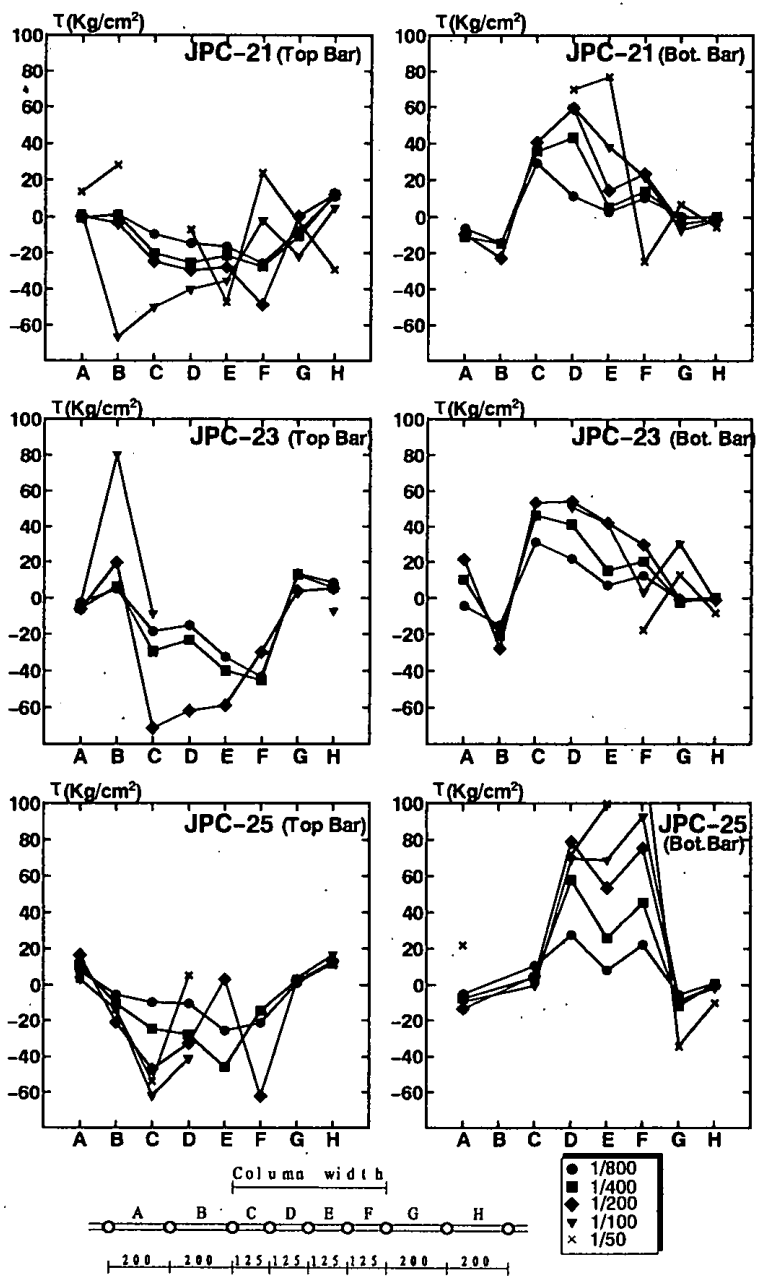

Fig. 20 Average bond stress distribution

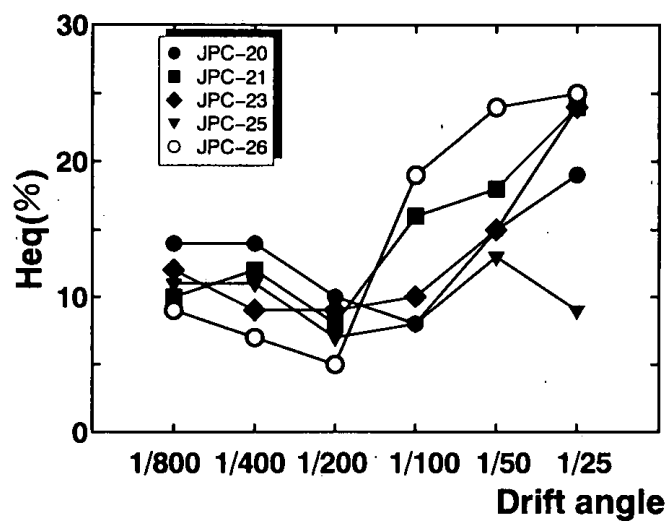

Fig. 21 Equivalent viscous damping ratio

\section{8 Energy Dissipation Capacity}

To quantify the energy dissipation capacity the equivalent viscous dumping is compared with the lateral drift angle in Fig. 21. The equivalent viscous dumping ratio was calculated by normalizing the dissipated energy at loading peak with an equivalent linear system. Before the yielding of beam bars, the precast specimens dissipated less energy compared to the ordinary reinforced concrete. However, the precast beam yielding type specimens dissipated more energy than JRC-20. On the other hand, the energy dissipated by JPC-25 was lesser than that of JRC-20 because of the shear deformation characteristics of this specimen.

\section{Conclusions}

A convenient building system for seismic resisting frames which involve the combination of precast concrete beams and columns acting compositely with cast in-situ beam-column joints is introduced. This system proves to be simple, economic and effective in resisting reversal loads due to earthquake actions.

The test results from nine interior beam-column joint specimens subjected to simulated seismic loading lead to the following conclusions:

1) Precast concrete specimens designed as beam yielding type showed a very ductile behavior and no differences were appreciated respect to the monolithic reinforced concrete specimen. The present precast concrete connections can sustain inelastic deformations and can be as ductile as those cast in-situ. Therefore, the structural design of frames using the present system can be done using the conventional methods.

2) The column depth to beam bar diameter ratio in the order of 26 is required to insure that the beam will reach its ultimate strength. On the other hand, for a concrete of 300 and steel bars of SD 390, a ratio of 23 is good to anchor bars in interior beam-column joints, but this anchorage length does not insure that the bond deterioration would be avoided.

3) The test results show that joint shear strength is similar to those values obtained in the past for monolithic beam-column joints. Discontinuity planes around the joint have no appreciable influence on the shear strength. The present system allows to have a simple arrangement of beam-column joint bars, similar to the conventional one (reinforced concrete) which lead to a similar behavior.

4) The deformation was concentrated not only at the critical section but also spread about $30 \mathrm{~cm}$ from 
the column face along the beam. Therefore, an undesirable concentration of plastic hinge rotation does not occur.

5) The prestressing bars proved to be effective to control cracks. However, the prestressing bars anchored at the end of the beam provided an undesirable concentration of cracks near the column. Also the prestressing load must be carefully investigated. because it could introduce a high stress concentration on the extreme of the beam near the column.

\section{References}

1) Kanoh, Y. : "Review of Japanese Precast Concrete System Used as Building Structures", Proceedings, US/Japan Seminar on Precast Concrete Construction in Seismic Zones V.2, Tokyo Japan, pp. 35 -54, October 29 31, 1986

2) Kanoh, Y., Yoshino, T. : “Review of Precast Concrete Frame Systems”, Japan Concrete Institute, V. 25, No. 3, pp. 33 40, March 1987

3) Imai, H. : "Overview of Precast Concrete Systems for Buildings in Japan", Japan Concrete Institute, V. 30, No. 11, pp. 16 25, November 1992

4) Imai, H., et al. : "Research on Precast Concrete Structures Where the Concrete Joints and Bar Joints are in Different Positions", Proceedings of Annual Meeting AIJ, pp. 723 724, September 1991

5) Kamimura, H. : “Utimate Shear Strength of Reinforce Concrete Beam-Column Joints”, Proceedings of Annual Meeting AIJ, pp. $1155 \sim 1156$, October 1975

6) Architectural Institute of Japan: "AIJ Standard for Structural Calculation of Reinforced Concrete Structures".

7) Architectural Institute of Japan: “Design and Construction of Precast Concrete Structures”, 1986.

(Manuscript received December 10, 1992 ; Paper Accepted October 28, 1993)

\section{和文要約}

\section{1.はじめに}

$$
\text { プレキャストコンクリート（以下 PCa) 工法の利点 }
$$
として, 高品質, 短工期, 安価, 安全が挙げられている。 PCaI法では，コンクリートおよび主筋の接合位置や 方法は構造物の挙動に大きな影響を与える。これらに関 しては未解決問題点が残されている。

初期のラーメン式 PCa 工法では図一1（a）のように 設計応力の小さい柱や梁の中央で部材を接合していた。 これはColumn Tree 方式と呼ばれている。この工法は 在来 PC 工法に比べ, 部材の形状が複雑で, 製作と運 搬が困難であったために姿を消した。

次の段階ではPCa の生産性を高めるため柱や梁の単 材を $\mathrm{PCa}$ 部材にし, 図一1(b) に示すように設計応力 の大きい柱梁接合部付近で接合するようになった。これ は単材方式と呼ばれている。単材方式は Column Tree 方式に比べ $\mathrm{PCa}$ 部材の製作や運搬の点で有利である が, 設計応力の大きい柱梁接合部, またはその近くで部 材を接合するため，主に梁下端筋に関して構造的な問題 が多い。

従来の PCa 工法では主筋が $\mathrm{PCa}$ 部材内に打ち込ま れていたので，鉄筋と $\mathrm{PCa}$ 部材の接合位置が同じ位置 になり，PCa 部材の生産性と耐震性とは互いに相入れ
ない工法となっていた。

ここで提案する $\mathrm{PCa}$ 工法では, $\mathrm{PCa}$ 部材には原則と して主筋を入れないので, 主筋と $\mathrm{PCa}$ 部材の接合位置 を同じにする必要がなく，図一1(c) に示すように $\mathrm{PCa}$ 部材は柱や梁の単材であるが, 主筋は PCa 部材の中央 部分で接合されている。この PCa 工法では，柱の主筋 は $\mathrm{PCa}$ 部材に配置されたシース内に配筋される。接合 する両主筋の端部は, 応力の小さい柱の中段で向かい 合っており，その部分では $\mathrm{PCa}$ 部材内のシースの両外 側に配置された 2 本の添え筋で重齐継手が行われてい る。PCa 部材を製作する時には，主筋の位置にシース と添え筋を配してコンクリートを打設する。現場では PCa 部材のシース内に主筋を入れ, 高強度モルタルを 注入するだけである。表一1に各方式の特徴を示す。

本 PCa 工法の現場での施工順序は, 下柱と左右の梁 $\mathrm{PCa}$ 部材を設置した後, 梁の主筋を通し, シース孔を ふさいだ後，接合部のあばら筋を置き，柱主筋を上より シース内に入れ, 下柱のシース内に高強度モルタルを図 一2 に示すように同時に注入する。次の接合部と梁上部 の場所打ちコンクリート部を打設する。その上に同種の モルタルを置いて上柱 $\mathrm{PCa}$ 部材を設置した後, 梁下端 筋と上柱主筋のシース內にモルタルを注入する。 
本研究の目的は, 本工法の耐震性能を在来 RC 工法 と比較するとともに, 梁の配筋 (1 段筋, 2 段筋), 柱せ いと主筋径の比 $(D / d)$, 柱梁接合部のせん断余裕度が 構造性能に与える影響を調べることである。

\section{2. 実験方法}

2.1 試験体

試験体は 9 体であり，その特徴を表一 2 と図一 3 に示 す。試験体は, 中高層建物の F 層部分を想定して, 柱と 梁の接合する部分を取り出し, 約 $2 / 3$ 縮尺の十字型試験 体とした。梁主筋の配筋方法と柱梁接合部のせん断耐力 を主な実験パラメータとした。

JRC-20は従来の場合打ち工法（たて打）である。 JPC-21，JPC-22, JPC-23, および JPC-27 は梁曲げ 降伏型に設計し，梁の曲げ強度をほぼ同じにして，梁主 筋の径を変えた。JPC-26も梁曲げ降伏型にし, 梁 $\mathrm{PCa}$ 部材には $\mathrm{PC}$ 鋼棒によって $40 \mathrm{kgf} / \mathrm{cm}^{2}$ の一様なプ レストレスを導入した。JPC-24,JPC-25，JPC-28は 柱梁接合部のせん断耐力を変化させ, 柱梁接合部のせん 断破壊型に設計した。梁の断面は図一 4 に示すように 40 $\mathrm{cm} \times 50 \mathrm{~cm}$ であり, PCa 部之場所打ち部のせいがそれ ぞれ $37 \mathrm{~cm}$ と $13 \mathrm{~cm}$ である。柱断面は全試験体で同一 とし，図一4に示すように $50 \mathrm{~cm} \times 50 \mathrm{~cm}$, 主筋は $16-$ D16 (SD 345)，せん断横補強筋は 4-D 10 (SD 295 A) @100である。柱梁接合部付近の配筋の一例を図一 5 に 示す。柱と梁の $\mathrm{PCa}$ 部材は横打ちした。図一6に示す ように梁の端面にはシャーコッターを設け; また，梁の 水平打継ぎ面には締め固めた後, 鉄筋棒で凸凹を設けた。 $\mathrm{PCa}$ 部材のコンクリート設計強度は $F_{\mathrm{c}}=300 \mathrm{kgf} / \mathrm{cm}^{2}$ である。また，注入モルタルの設計強度は $600 \mathrm{kgf} / \mathrm{cm}^{2}$ である。表一 3 にコンクリートと鉄筋の試験結果を，ま た表一4にモルタル強度を示す。

\section{2 加力方法上測定方法}

1）加力方法：図一7に示すようにジャッキを用いて柱 には常時 $60 \mathrm{kgf} / \mathrm{cm}^{2}$ の一定軸力を作用させた状態で, 梁端部のアクチュエータで一方に圧縮力を他方に等量の 引張力を与えた。その反力は, 柱の上下の両側にある油 圧ジャッキでとった。

加力履歴を図一 8 に示す。梁端のアクチュエータを制 御し, 全体変形角を $R=1 / 800$ で 1 回, $1 / 400,1 / 200$, $1 / 100 ， 1 / 50$ で各 2 回正負繰返し加力行った後，1/25 ま で加力した。

2）測定方法：試験体の表面では，図一9のように柱の 上下に埋め込まれたボルトにピン支持された測定冶具で 全体の部材変形を測定し，この值で加力を制御した。ま た同時にひび割れ状況を観察した。試験体の裹面では, 図一10のように接合部に埋め込まれたボルトで，測定 冶具をピン支持し，柱と梁の変形を測定した。柱梁接合
部の変形は, 対角線に沿って測定した。また柱と梁にパ イゲージを取り付け，材軸方向の局部的な変形を測定し た。

\section{3. 実験結果}

3.1 ひび割れ状況

図一 11 に層間変形角 $R=1 / 50$ 時のひび割れ状況を示

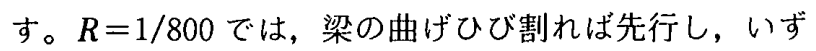
れの試験体でも柱梁接合部にまだせん断ひび割れが生じ なかった。 $R=1 / 100$ で梁曲げ降伏型では梁主筋が完全 に降伏して接合部にせん断ひび割れが生じた。全体的に 梁端部には曲げ変形のためひび割れが集中した。終局時 でも梁曲げ降伏型では破壊過程には大きな差が認められ なかった。JPC-26はプレストレスのため梁端にひび割 れが局部的に集中し，他ではひび割れが少なかった。柱 梁接合部せん断破壊型では， $R=1 / 400$ で接合部にせん 断ひび割れが生じ,終局時には破壊が接合部に集中した。 梁端部の打継ぎ面には縦のひび割れが生じていたが，ひ び割れ幅は $R=1 / 50$ までは大きくならなかった。

\section{2 荷重変形曲線}

荷重変形曲線を図一 12 に，また最大耐力の実験値と 計算值を表一 5 に示す。梁曲げ降伏型の試験体は， $R=$ $1 / 200$ で梁主筋が降伏し，ほぼ同じ $Q-\delta$ 曲線を示した。 最大耐力は，いずれも最後の段階で達し，繰り返しによ る耐力低下が見られなかった。

柱梁接合部せん断破壊型 JPC-24 と JPC-28 では, $R$ $=1 / 50$ へ行く途中で梁端が曲げ降伏した直後に, 接合 部がせん断破壊し始めた。JPC-25 は接合部がせん断破 壊始めた。JPC-25 は接合部がせん断破壊した。

JPC-26 はプレストレスのため鉄骨造のような復元力 特性を示した。

\section{3 変形の割合}

図一 13 に全体変形に占める各部材変形の割合を各サ イクルの正荷重時ピークについて示す。各部材の変形の 割合は,ひび割れや破壊の進行とよく対応している。柱， 梁および接合部の変形の割合では, 梁降伏型では梁の変 形成分が約 $90 \%$ を占めている。しかし最終的に柱梁接 合部がせん断破壊した JPC-25 では, 接合部の変形成 分が急激に增大した。

\section{4 梁の打継ぎ部のずれ変形}

図一14に梁荷重と梁打継ぎ部のずれ変形の関係を示 す。梁の水平打継部のずれ変形は 0.2 から $0.8 \mathrm{~mm}$ 程度 であったが，JPC-21 の試験体では最終段階では変形が 約 $3 \mathrm{~mm}$ までと大きくなった。

全体的に打継部に添うひび割れは少なく，梁の一体性 は確保されていた。

\section{5 柱梁接合部のせん断変形}

図一15 に柱梁接合部のせん断㐫力一せん断変形曲線を 
示す。梁曲げ降伏型ではいずれも，せん断変形が小さく ほぼ同じ曲線をしている。接合部せん断破壊型の JPC24 と JPC-28 はほぼ同じ曲線を示し， $R=1 / 50$ でせん 断破壊したが，最後に接合部の帯筋比の小さい JPC-28 のせん断変形が JPC-24 より大きくなった。JPC-25で も接合部がせん断破壊し， $R=1 / 50$ で最大せん断応力 を示した。図一16は，十字形柱梁接合部のせん断耐力 に関する既往の一体打の実験結果之, 梁筋を特殊な工法 で定着した場合の実験結果と本実験結果を比較したもの である。本工法の耐力が他の PCa 工法の実験結果より 大きく,一体打ちのものと同等であることが認められる。 3.6 梁端部のモーメントー曲率関係

図一17に梁端部のモーメントと各位置の曲率の関係 を示す。梁曲げ降伏型の試験体では，曲げ変形が柱面よ り $30 \mathrm{~cm}$ までの梁端部に及んだ。

図一18に梁付根部からの部材変形の推移を示す。最 初の段階で JPC-20 と JPC-21 を比較すると JPC-21 の曲率の方が少し小さいが, 最終的に梁付根に変形が集 中したため大きくなる傾向をした。

\section{7 ひずみ分布}

各サイクルのピーク時における梁の下端筋のひずみ分 布を図一19に示す。主筋に細径 D 16 を用いた梁曲げ降 伏型 JPC-20 と JPC-21 では, 柱梁接合部内の下端筋 が王縮側柱面位置で引張ひずみに転化しないで王縮ひず みを示し，付着が良好であった。主筋に 4-D22を用い た JPC-23では王縮側柱面位置ではひずみが引張ひず みに転化した。主筋に 8-D22 を用いた接合部せん断破 壊型の JPC-25ではひずみが弾性域内であった。これ らの傾向は梁上端筋に関しても言える。
図一 20 に梁主筋の平均付着応力度 $\tau$ の分布を示す。 鉄筋が降伏した後の付着応力度は, 鉄筋の $\sigma-\varepsilon$ 関係を Ramberg-Osgood モデルによって仮定し算出した。全 体的に付着は良好であったが, JPC-23では梁主筋が太 いため付着応力 ては小さくなる傾向があった。

\section{8 等価粘性娍衰定数}

図一21 に等価粘性诚素定数 $h_{e q}$ と層間変形角の関係 を示す。梁主筋が降伏する前では JRC-20の $h_{\text {eq }}$ が JPC-21 より大きかった。最終的に PCa の梁曲げ降伏 型の試験体ではエネルギー吸収が大きくなった。JPC25 では柱梁接合部がせん断破壊したため, $h_{\text {eq }}$ が低かっ た。

\section{4. まとめ}

以上述べた実験結果は次のようにまとめられる。

1) 本 PCa 工法による梁曲げ降伏骨組は荷重変形曲線 や鉄筋のひずみ分布などに関して一体打ちの RCI法 とほぼ同じ性能を示すことが確認された。

2）コンクリート強度が $F_{c}=300 \mathrm{kgf} / \mathrm{cm}^{2}$ で梁主筋が $\mathrm{SD} 390$ 場合では鉄筋の径 $d$ と接合部のせい $D$ の比 $(D / d)$ が 23 あれば接合部内で十分定着できるが, 付 着低下が避けることができない。

3) 本 PCa 工法の柱梁接合部のせん断耐力は, 柱と梁 の端部でコンクリートの打継ぎがあっても一体打ちのも のと同等である。

4）梁の降伏域は梁端部から $30 \mathrm{~cm}$ ぐらいまで及んだ。

5）梁にプレストレスがあると，ひび割れを制御するこ とができるが, 梁端部にひび割れが集中する。 